\title{
Indigenous Peoples and Relationships The Power: A Critical Assessment Public Policy Against Discriminatory Parmalim
}

\author{
Tonny Pangihutan Situmorang \\ Lecturer of Political Science Faculty of Social and Political Sciences, University of North Sumatra
}

\begin{abstract}
Indonesia's Constitution noted that every community has the same rights as citizens. However, the narrative of the constitutional language is not in line with the implementation of a policy of discrimination because they are felt to indigenous peoples Parmalim community is no exception. Parmalim an indigenous people in North Sumatra that suffered discrimination policies in the name of development and technological progress. Nowadays, when it recorded the number of people in North Sumatra Parmalim is 5026 persons or 0.14 of 12,985,075 inhabitants of the population of North Sumatra. Parmalim Indigenous Peoples are still experiencing difficulties in defining itself. Do beliefs and rituals for which they believe in and practice religion or not. On the other hand, they also did not gain official recognition from the state about whether it pertained Parmalim trust or an indigenous community. The root of this problem is due to a very unequal power relations and exploitative towards Parmalim. The author analyzes this issue with critical paradigm by banging social phenomena and in uncovering discrimination etnometodologis power relations that make experiencing marginalization of indigenous peoples.
\end{abstract}

Keywords: Indigenous Peoples, Parmalim, Relations Counsel, Discrimination

\section{INTRODUCTION}

Indigenous peoples have lived and evolved for thousands of years in the archipelago, the area which is now the Republic of Indonesia. Thousands of indigenous people with different backgrounds has historical ties closely with their traditional territory, practicing the values of a strong spiritual, customary laws governing the harmonization of community life, social structures and traditional institutions are unique, the management of the lands, territories and natural resources through traditional knowledge, as well as the rules of coexistence with other communities. ${ }^{1}$ However, the Indonesian government has not had a comprehensive and integrated policy with regard to the recognition and protection of the rights of indigenous peoples in Indonesia. This is reflected in the wide range of other legislation that has not fully recognized the existence, rights and aspirations of indigenous peoples. $^{2}$

In Act No. 41 of 1999 on Forestry, the government uses the terminology of indigenous and tribal peoples in article 4 which states control the forest by the state taking into account the rights of indigenous people, along the fact still exist and be recognized, and not contrary to the national interest. Their use of the term

${ }^{1}$ J.G. Gimpel dan J.E. Schuknecht (2003) "Political Participation And The Accessibility Of The Ballot Box" Jurnal Pergamon Political Geography, page 471-488.

${ }^{2}$ Dokumen Aliansi masyrakat Adat NusantaraMengarusutamakan Masyarakat Adat dalam Adaptasi dan Mitigasi Perubahan Iklim, 2011, Bandung : TELAPAK Gedung Alumni IPB indigenous and customary law in a variety of product legislation, indicating that the Indonesian government has no understanding of the unity of indigenous peoples.

This leads to a lack of sensitivity to various problems in indigenous communities caused by the vagueness of this status. The existence of indigenous and tribal peoples should be recognized in advance by the government, but no explanation could be a reference to the definition of indigenous and tribal peoples, as well as the recognition mechanism. Without these two things, the recognition of the existence, rights and aspirations of indigenous peoples, do not have a reference to a clear substantive and operational, which required the government to recognize and protect the existence and their rights in the various sectoral policies in Indonesia.

Parmalim society is one of the indigenous communities. Long suffering and injustice experienced by indigenous peoples in Indonesia one of them comes down from the US removal of indigenous peoples in the political process of public policy making. Development policies that exist today often rise to various conflicts and adverse ecological impact on indigenous peoples and other local residents. ${ }^{3}$

It is also the point of the main problems faced by indigenous peoples in North Sumatra Parmalim. currently carrying amount Parmalim

\footnotetext{
3 “Hapuskan Diskriminasi Terhadap Masyarakat Adat”in Harian Kompas http://nasional.kompas.com/read/2009/03/16/19123451/H apuskan.Diskriminasi.Terhadap.Masyarakat.Adat. downloaded in 20 Mei 2017, at17.48 Wib.
} 
community in North Sumatra is 5026 persons or 0.14 per cent of the $12,985,075$ inhabitants of the population of North Sumatra. Parmalim society is one of the original indigenous peoples and traditional in North Sumatra, which spread mostly in Toba Samosir, Simalungun, Samosir, Humbang Hasundutan to Medan with the religious area is in the center-Laguboti Hutatinggi. Some of the personal ancestors in the land of Batak is considered as Ugamo Malim, the Raja Uti, Simarimbulubosi and Sisingamangaraja. ${ }^{4}$ Institutionally local adherents of Parmalim held the belief that Ugamo Malim who is also a genuine belief Toba Batak tribe and is a continuation of the old religion in the land of Batak. ${ }^{5}$

${ }^{4}$ Sitor Situmorang, Toba $\mathrm{Na}$ Sae, 2004, jakarta : Komunitas bambu, page 245.

${ }^{5}$ Ahmad Syafii Mufid, Dinamika Perkembangan Sistem Kepercayaan Lokal di Indonesia, Kementerian Agama RI Badan Litbang dan Diklat Puslitbang Kehidupan Keagamaan Jakarta 2012, page 11. 


\section{Figure 1.1. Ritual Belief Parmalim}

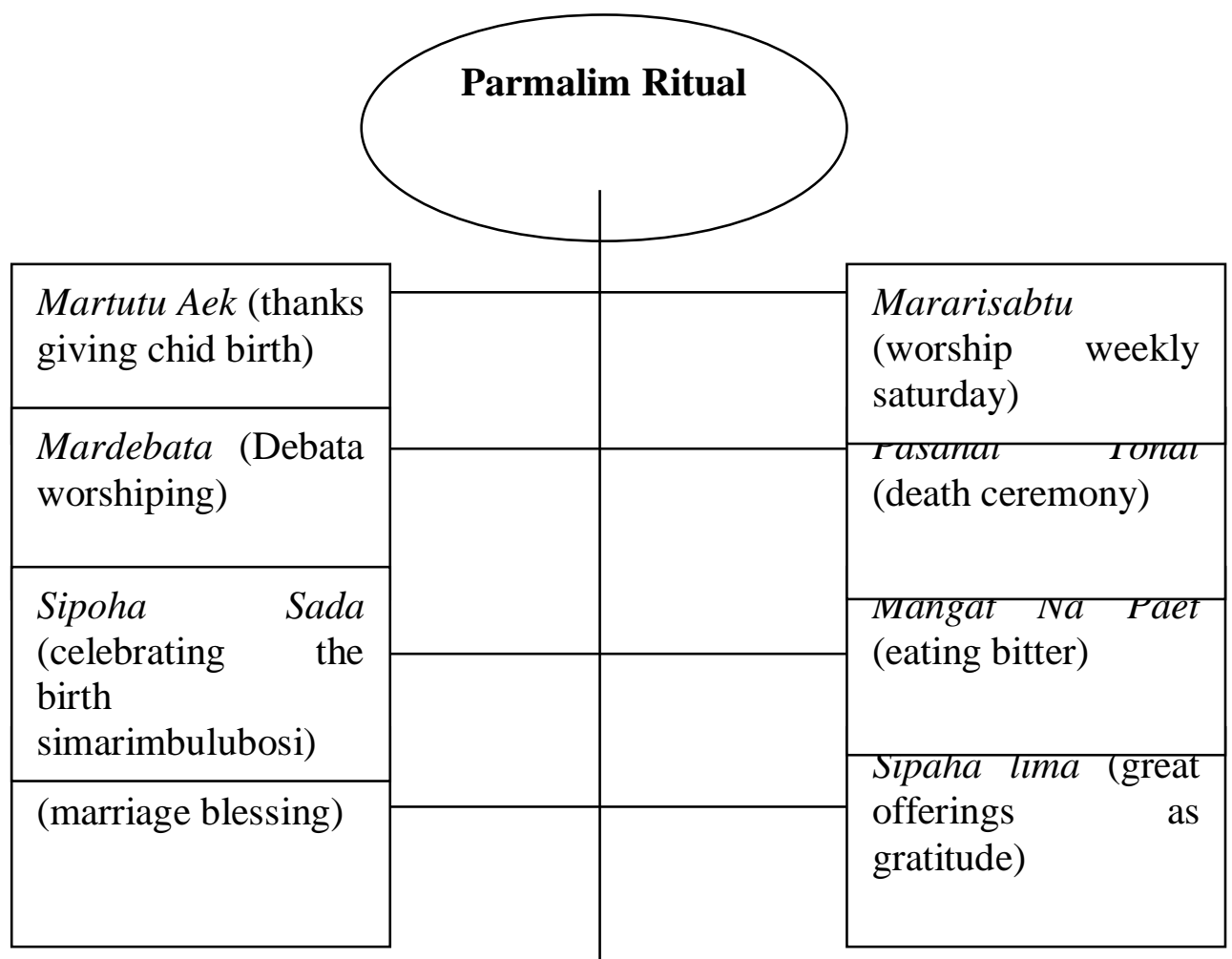

Source: infographic tirto.id/various sources

According to Decree No. IV / MPR / 1978, the state is only recognized Malim as belief in God Almighty, and not classified as a religion. MPR's history motive countries wishing to regulate the amount of religion can grow, and anxious when new religions so easily arise, in Indonesia. It makes a number of rights as a citizen Parmalim restricted. Where the right thing Parmalim restricted community would automatically lead to the discrimination faced by people Parmalim itself.

If it is so, of discrimination and intolerance perceived Parmalim society can not be avoided. Because, by nature, Parmalim Society has animism, believing that each element and object in this world has a soul which must be respected. This means that the award of the universe is very strong. Sea, forests, rivers, trees, rocks and even the land has its own value in the balance with humans. ${ }^{6}$

6"Hapuskan Diskriminasi Terhadap Masyarakat Adat"in Harian Kompas http://nasional.kompas.com/read/2009/03/16/19
Contrary to this, Parmalim vulnerable communities excluded from management areas near mining concessions, oil palm plantations, timber and other so there can fulfill their role as guardians of family and community survival Parmalim. Eventually overtake them in the political process, even in the history of democracy is only one member of the Legislative Council who had sat in parliament making processes related policies empowering communities Parmalim not maximized.

This paper is going to study the problems related to: Indigenous Peoples and Relationships The Power: A Critical Assessment Public Policy Against Discriminatory Parmalim which the end of the policy paper recommending how highly skewed in relation to the existing policy.

\section{RESEARCH METHODOLOGY}

This paper is a qualitative research with the positivist paradigm. Where researchers collected data by interviewing key actors Parmalim society.

123451/Hapuskan.Diskriminasi.Terhadap.Masy arakat.Adat. downloaded in 20 Mei 2017, at $17.48 \mathrm{Wib}$ 
While this research is secondary data obtained by researchers of international journals, national journals, books and media releases. Research data collection is also done through a process of review of the documents or reports related to the focus of research. Researchers also collected various forms of qualitative data related to indigenous peoples, communities Parmalim and Elections also a useful document for the development of a deeper understanding of this research.

\section{RESULTS AND DISCUSSION}

A.Kebijakan Discriminatory

By unprotected substrate Community customs territory Parmalim a part in and it contains agrarian resources such as land and diverse natural resources, is an integral part of life Parmalim itself. Parmalim Community customs territory is not only seen as a source of economic and community life Parmalim, but also the identity that it contains the value system, social, cultural and spiritual, which is inherited. With the value system Parmalim Society continues to maintain and defend their traditional territory.

Efforts in maintaining, preserving and maintaining the indigenous territories have experienced a very heavy challenge during the 32 years of the New Order regime and even the Government is continuing to Reform Order. Various policies and laws issued has led to practices of looting, destruction and removal of the region Parmalim Society. Territories of indigenous is generally controlled by others through a system of permits issued by the government in the form of Hak Guna Usaha (HGU), Right to Build (HGB), Business License Timber Forest Products (IUPHHK- first HPH), Business License Results Industrial plantation forest (HTI IUPHHTI-first) and the Mining region (KP) in the living area Parmalim.

The implication, Community Parmalim forced to surrender by a licensing system that eliminates the fundamental rights, as well as the causes of impoverishment and food insecurity in their region. Even his area of conservation and protected areas managed by the Society Parmalim still on the threat to the conservation of nature .Meanwhile, ignorance of the existence of indigenous peoples' socio-political structure is also accompanied by a waiver of their own free will to assess, decide and control all forms of development plans conducted in Parmalim Community living space. ${ }^{7}$

From the political point of law which is run country so far to be understood that both forms of neglect are related to one another. The key is the representation and power limitations Parmalim Society for the fight.

Parmalim communities have challenges with the lack of state administration services and public services such as education, communication, transport and health. In particular, indigenous peoples who still profess ancestors and are not included in the major religions are officially recognized by the government. Public confidence Parmalim can not obtain ID cards were later implicated in the loss of their rights as citizens to participate in the elections as well as the loss of access to education and health. The direct impact of the absence of administrative services and public services, the community in Indonesia occupies the lowest position in the economic, education and health.

\section{B.Relation Authorization}

In the constitution in terms of seizing power or be involved in the political process can never be separated from how people Parmalim able to participate in the general election. ${ }^{8}$ Furthermore, efforts to fight the power relations between the state and indigenous peoples these days increasingly unfair. As; inaccuracies in the domination of the majority-minority, humble mutual trust behaviors to issue verbal violence against children Parmalim transformed into a truth as set unilaterally without regard to the values of tolerance in diversity and diversity in Indonesia.

majority-minority issues, gender inequity and intolerance faced by communities Parmalim lately is unjust power relations that must be resolved as soon as possible to enter the political spaces itself through Election.

\footnotetext{
${ }^{7}$ Abdon, Nababan, (2014), Garis Garis Perjuangan (Platform) Dan Usulan Agenda Dari Aliansi Masyarakat Adat Nusantara (Aman) Kepada Calon Presiden Dan Calon Wakil Presiden Republik Indonesia Periode 20142019 Menata Hubungan Masyarakat Adat Dengan Negara Menuju Bangsa Indonesia Yang Berdaulat Secara Politik, Mandiri Secara Ekonomi Dan Bermart Abat Secara Budaya, Jakarta : Rumah Aman

${ }^{8}$ Jawahir Thontowi, Perlindungan dan Pengakuan Masyarakat Adat dan Tantangannya dalam Hukum Indonesia, Yogyakarta : Fakultas Hukum Universitas Islam Indonesia, Jurnal Hukum Ius Quia Iustum No. 1 Vol. 20 Januari 2013, page22.
} 
General election activities is also one means of distribution rights of citizens very principle. Therefore, in the framework of the implementation of the rights of citizens is imperative for the government to guarantee implementation of the elections in accordance with constitutional predetermined schedule. Constitutional rights are basic rights for all the people of Indonesia, including for indigenous peoples who still upholds the values of customary law.

Moreover, Indonesian society is a society that has a very pluralistic religious tradition, not only mainstream institutionalized religion, but also the confidence of local and persisted until now. Local beliefs with the teachings of systems, traditions, followers is something that lives in the community until now, even before the independent Indonesian state. Although it looked stagnant and helpless in the social life of religious, economic and political, but the community of local followers trust is undergoing development, tide, so does the confidence Parmalim. ${ }^{9}$

\section{C.Recognition of Rights of Peoples, Parmalim}

Globalization makes it increasingly undermining the community role Parmalim as the guardian of survival communities (independence fulfillment) as a result of drastic changes in management area custom that does not put people Parmalim as one of the actors who manage, utilize and take care of the sources of life of indigenous peoples themselves ,

Perspectives, interests and voices of indigenous women over the area of governance and living resources that are owned by people Parmalim often do not get a place to be heard. Empirical experience shows marginalizing the role of community groups such Parmalim in decision-making and access to information with various limitations and restrictions of their social roles and functions.

The main concern for the rights and special needs of the community Parmalim on these groups apply to outsiders also corrects the internal mechanisms in decision-making in the community in case of discrimination. Parmalim society too have limitations in participating in the political sphere. Temporary special measures

\footnotetext{
${ }^{9}$ Wakhid Sugiyarto dan Asnawati, 2012, Dinamika Kepercayaan Parmalim Di Kabupaten Samosir \& Toba Samosir Sumatera Utara, Kementerian Agama RI Badan Litbang dan Diklat Puslitbang Kehidupan Keagamaan Jakarta tahun 2012 page 11-23.
}

that are intended Parmalim society in political participation is not a space for people Parmalim itself. Limitations in the stock levels of formal education often limit the nomination of indigenous women to get involved. Temporary special measures that are intended Parmalim society in political participation is not a space for brand .. Limitation levels of formal education in exchange candidacy Parmalim often limit people to get involved that they should achieve.

\section{CONCLUSIONS}

Parmalim community power relations in the context of a state is at a point that is not fair. It is closely related to the public authority Parmalim the sustainability of life and livelihood of indigenous families and communities Parmalim society itself.

Despite the existence of the Parmalim recognized by the state but not followed by the recognition of the public authorities Parmalim in social, economic and political. Parmalim peoples' rights in the state often escape look the rights of national and state because of the inequality of accessibility. With the recognition of the community Parmalim as part of a seeker of trust, then the public Parmalim future can be involved and voice in strategic decision-making in the realm of politics, budgets and policies.

Then, no less important is the community management area that is closely related Parmalim sources of livelihood are important in ensuring the survival of offspring and specifically Parmalim public confidence can be accessed collectively. Thus policies that discriminate against Parmalim Society can be resolved.

\section{REFERENCES}

\section{Book:}

Situmorang, Sitor, (2004) Toba Na Sae, jakarta : Komunitas bambu.

\section{Journal :}

Abdon, Nababan, (2014), Garis Garis Perjuangan (Platform) Dan Usulan Agenda Dari

Aliansi Masyarakat Adat Nusantara (Aman) Kepada Calon Presiden Dan Calon Wakil Presiden Republik Indonesia Periode 2014-2019 Menata Hubungan Masyarakat Adat Dengan Negara Menuju Bangsa Indonesia Yang Berdaulat Secara Politik, Mandiri Secara Ekonomi Dan Bermart Abat Secara Budaya, Jakarta : Rumah Aman. 
Gimpel dan J.E. Schuknecht (2003) "Political Participation And The Accessibility of The

Ballot Box" Jurnal Pergamon Political Geography, hal. 471-488.

Sugiyarto, Wakhid dan Asnawati, (2012), Dinamika Kepercayaan Parmalim Di Kabupaten Samosir \& Toba Samosir Sumatera Utara, Kementerian Agama RI Badan Litbang dan Diklat Puslitbang Kehidupan Keagamaan Jakarta tahun 2012.

Syafii, Ahmad Mufid, Dinamika Perkembangan

Sistem Kepercayaan Lokal di Indonesia, Kementerian Agama RI Badan Litbang dan Diklat Puslitbang Kehidupan Keagamaan Jakarta 2012.

Thontowi, Jawahir, (2013)Perlindungan dan Pengakuan Masyarakat Adat dan

Tantangannya dalam Hukum Indonesia, Yogyakarta : Fakultas Hukum Universitas Islam Indonesia, Jurnal Hukum Ius Quia Iustum No. 1 Vol. 20 Januari 2013.

\section{Media :}

"Hapuskan Diskriminasi Terhadap Masyarakat Adat" dalam Harian Kompas http://nasional.kompas.com/read/2009/03/16/ 19123451/Hapuskan.Diskriminasi.Terhadap.Mas yarakat.Adat. downloaded in20 Mei 2017, at 17.48 Wib.

\section{Document :}

Document Aliansi masyrakat Adat NusantaraMengarusutamakan Masyarakat Adat dalam Adaptasi dan Mitigasi Perubahan Iklim, 2011, Bandung : TELAPAK Gedung Alumni IPB 